\title{
KARYOTYPE AND NOR-BANDING OF MITOTIC CHROMOSOMES OF SOME Vitis L. SPECIES ${ }^{1}$
}

\author{
NEIVA IZABEL PIEROZZI
}

ABSTRACT - Chromosome studies were performed in $V$. champinii, $V$. cinerea, $V$. girdiana, $V$. labrusca, $V$. rotundifolia, $V$. rupestris and $V$. vinifera with the purpose of species characterization using chromosome morphometric data and NOR banding. A median ideogram was obtained for each species. The karyotype formula obtained varied from $7 \mathrm{~m}+12 \mathrm{sm}$ to $9 \mathrm{~m}+11 \mathrm{sm}$. The species showed moderate chromosome asymmetry values according to TF\% form, Stebbins, Romero Zarco and Paszko indices. V. champinii and $V$. girdiana were apart from the other species by $\mathrm{CVcl}$ and $\mathrm{CV}$ ci graphic representation and also formed a group apart in the dendrogram based on Euclidian distances. The chromosome pair number 3 harbors the secondary constriction and a satellite segment in all species analyzed with Giemsa staining and it may be the same observed after NOR banding technique. It seems that the process of speciation in the North American Euvitis species studied involved some discrete changes in chromosome morphometry which have been reflected in the asymmetry index.

Index terms: karyotype, NOR-banding, mitotic chromosomes, Vitis, Vitaceae.

\section{ESTUDOS CROMOSSOMICOS DE ESPÉCIES DE Vitis}

RESUMO - Estudos cromossômicos foram efetuados em $V$. champinii, $V$. cinerea, V. girdiana, $V$. labrusca, $V$. rotundifolia, $V$. rupestris e $V$. vinifera com a finalidade de caracterização das espécies, usando dados de morfometria cromossômica e do bandamento NOR. Foi obtido um ideograma médio para cada espécie estudada. A fórmula cariotípica variou de $7 \mathrm{~m}+12 \mathrm{sm}$ a $9 \mathrm{~m}+11 \mathrm{sm}$. As espécies mostraram assimetria cariotípica moderada pelos índices de TF\% forma, Stebbins, Romero Zarco e Paszko. $V$. champinii e $V$. girdiana ficaram à parte das demais espécies pela representação gráfica de $\mathrm{CVcl}$ e $\mathrm{CV}$ ci e também pelo dendrograma simplificado obtido pelo método de distância Euclidiana. O par cromossômico n ${ }^{0} 3$ apresentou constrição secundária e segmento satélite nas espécies analisadas com Giemsa, podendo ser o mesmo evidenciado pelo bandamento NOR. Parece que o processo de especiação das espécies de Euvitis americanas estudadas envolveu mudanças discretas na morfometria dos cromossomos a qual se refletiu no índice de assimetria cromossômica.

Termos para indexação: cariótipo, bandamento NOR, cromossomos mitóticos, Vitis, Vitaceae.

\section{INTRODUCTION}

Vitis L. (Vitaceae) is an economical important genus of wide geographical distribution over lands of the North Hemisphere (North American, European and Asiatic groups). The southeast region of North America is especially rich in wild Vitis species (OLMO, 1979). The Old World $V$. vinifera is undoubtedly the most important species and its ancient culture has given rise to thousands of different varieties adapted to different regions and soil, not only in temperate lands but also in subtropical and tropical ones where the grape culture has been growing very well. Though not holding the same importance as $V$. vinifera, some of the wild grape species such as $V$. rupestris or $V$. rotundifolia, for instance, have been used as rootstock to select $V$. vinifera varieties. Others such as $V$. labrusca are employed in breeding programs resulting in many cultivars cultivated as table grapes in Brazil or employed in the juice industry (SOUSA, 1996).

Vitis classification is still a controversial subject, especially concerning American species, where number of valid species varies according to the author (SOUSA 1996; ALVARENGA et al., 1998). The genus encompasses approximately 60 species which is divided in two sections, Euvitis and Muscadinia according to chromosome number and

\footnotetext{
${ }^{1}$ Trabalho Sinfruit 054 - Simpósio Internacional de Fruticultura - Avanços na Fruticultura (17 a 21 Outubro)

${ }^{2}$ Pesquisadora. CPDP Recursos Genéticos Vegetais, Instituto Agronômico de Campinas (IAC). Av. Barão de Itapura, 1481. Caixa Postal 28. Campinas, SP, Brasil. 13012-970.
} 
external morphological characteristics (SOUSA, 1996; THIS et al., 2006).

Even though Vitaceae is not considered a large family, less than $7 \%$ of its 945 species have the chromosome number determined and less than $1 \%$ of these species have some information about chromosome morphology (GOLDBLATT; JOHNSON, 2006). The first chromosome count in the genus Vitis was done by Ghimpu, in 1927, who established $2 \mathrm{n}=38$ for $V$. vinifera (cited by OLMO, 1937). Since then, cytological work on grapes have been predominantly centered on the detection of chromosome number. Moreover, little is known about the interspecific genomic affinities of Vitis by cytological comparative studies (ALLENWELDT; POSSINGHAN, 1988; VILJOEN; SPIES, 1995). Some attempts towards Vitis chromosomal characterization were carried out by some authors who tried various procedures to get a satisfactory chromosome spreading and staining for chromosome characterization (RAJ; SEETHAIAH, 1969, 1973; MARTENS; REISCH, 1988; PATIL; PATIL, 1992, for instance). Despite efforts, all of these authors were unanimous in their conclusion that the species had very small and numerous chromosomes. Knowing these difficulties and also that the karyotype analysis is a useful tool for characterizing germplasm, chromosomal studies were carried out on seven Vitis species by employing NOR banding and Giemsa staining techniques in an attempt towards species characterization, aiming at further knowledge on a possible relationship among them at chromosomal level, therefore amplifying the chromosomal data on the Vitaceae family.

\section{MATERIAL AND METHODS}

V. champinii Planchon, V. cinerea (Engelm) in Gray Engelm ex Millardet, $V$. girdiana Munson, $V$. labrusca L., V. rotundifolia Michaux, V. rupestris Scheels and $V$. vinifer $a$ L. were employed in chromosome studies. The especies belong to the Vitis collection of the Vegetable Genetic Resources data Center at the Agronomical Institute of Campinas - IAC (CPD Recursos Genéticos Vegetais-Instituto Agronômico de Campinas). Roots from rooted hardwood cuttings were collected, pre-treated with a saturated solution of para-dichlorobenzene at $16^{\circ} \mathrm{C}$ for 3 hours, fixed at 3:1 (ethanol and acetic acid, respectively) solution and stored at $-20^{\circ} \mathrm{C}$ until the cytological analyses. Fixed roots were softened in pectinase/cellulase at $37^{\circ} \mathrm{C}$ for 1 hour and then squashed in $45 \%$ acetic acid solution. Some slides were stained with a fresh $2 \%$ Giemsa solution for 2 to 5 minutes at room temperature, dried and mounted with Permount (Fisher).
The mean values were calculated for the total haploid chromosome length (THCL), the longest (L) and the shortest chromosome (S) length, the ratio of the longest to the shortest chromosomes $(\mathrm{L} / \mathrm{S})$, the difference between the longest and the shortest chromosomes (L-S), the average chromosome length in the metaphase $(\chi \mathrm{m})$, the average of centromeric indices and the karyotype asymmetry index TF\% (HUZIWARA, 1956) for each Vitis species. The centromeric index was calculates according to Levan et al. (1964).The F- and Tukey-tests were applied onto the karyomorphometric data. The species were also analyzed by other three karyotype asymmetry indices, Stebbins (1958) two-way system, Romero Zarco (1986) intra (A1) and inter chromosomal (A2) asymmetry, and by Paszko AI (2006) which comprises coefficient of variation of chromosome length $(\mathrm{CVcl})$ and of centromeric index $(\mathrm{CVci})$ with the purpose of verifying which one distinguish in a better way the species. The Karyotype formulae and ideograms for each species were obtained by using chromosome measurements. NOR-banding were performed according to Howell and Black (1980) to visualize the nucleolar regions which were active in the last interphase.

\section{RESULTS AND DISCUSSION}

The karyotype analyses performed in the seven Vitis species studied were useful for the genome characterization mainly among American species of Euvitis section which have shown the same chromosome number. It was possible to observe differences among them through chromosome morphometry criteria (Tables 1 and 2). The karyotype formulae were $7 \mathrm{~m}+12 \mathrm{sm}$ for $V$. champinii, $V$. cinerea, $V$. girdiana and $V$. labrusca, $8 \mathrm{~m}+11 \mathrm{sm}$ for $V$. rupestris and $V$. vinifera, and $8 \mathrm{~m}+12 \mathrm{sm}$ for $V$. rotundifolia (Table 2 ).

The species showed a moderate karyotype asymmetry and among the four indices, Paszko index showed the best species separation with a better dispersion (Figure 1).

Observing the graphic representation $V$. champinii and $V$. girdiana were apart from the other species which formed a closed cluster. The pattern of dispersion of the species studied showed many similarities with the dendrogram obtained based on Euclidean distances (Figure 2). It is possible to see two main basic clusters in the dendrogram using karyological data. One of them comprised $V$. champinii and $V$. girdiana and the other comprised the remaining species. According to the dendrogram $V$. cinerea and $V$. rupestris showed the closest affinity when compared to the others. $V$. champinii is a 
species with a contradictory taxonomic position. It was firstly described as species and later was considered as a natural hybrid between $V$. candicans and V. rupestris (MOORE, 1991; SOUSA, 1996). The karyomorphological data obtained for $V$. champinii and $V$. rupestris have shown significant differences between them, supporting more $V$. champinii classification as a species than a hybrid. This species also showed a more asymmetric karyotype when compared to $V$. rupestris (Table 2 and Figures 1 and 2) suggesting that this species have appeared first than $V$. champinii.

Although $V$. rotundifolia has been characterized by a different chromosome number, this species showed some similarities with $V$. cinerea and $V$. rupestris which was characterized by lower values for $\mathrm{CVcl}, \mathrm{A} 2$ and Paszko AI which pointed to a less asymmetric karyotype. These species grow well in moist to dry (REISCH; PRATT, 1996). Though $V$. vinifera is a species native to European continent it presented some similarities with the American wild grapes studied through chromosome morphometry. However, at molecular level the use of single nucleotide polymorphism (SNP) in grapes has shown differences among some Vitis species including $V$. labrusca (MYLES et al., 2010). V. vinifera seems to be a species with karyotype polymorphism among its varieties, as inferred after comparisons between the present results obtained for 'Italia' variety to the others obtained for different varieties cited in literature (TAKUSAGAWA, 1952; RAJ; SEETHAIAH, 1973; PATIL; PATIL, 1992, for instance). Variations in chromosome measures and centromeric position which result in different degrees of karyotype asymmetry have appeared in other cultivated plants such as reported in diploid cultivars $(2 \mathrm{n}=60)$ of Agave tequilana (PALOMINO et al., 2008) or in some genotypes of sweet pepper Capsicum annuum (ROHAMI et al., 2010), for instance. It seems that these karyological differences among varieties/genotypes within the same species may be a consequence of discrete quantitative genomic changes due to small chromosomal rearrangements which could be raised by natural or mainly by artificial intercrossing among varieties allowing them to a better adaptation to the soil and the climate in the regions they have been grown. In fact, since Vitis is a millenary culture as reported through archeological findings (MITANI et al., 2009), it is predictable some degree of karyotype variation among the varieties, although these variation have not impeded many inter varietal crossings which have resulted in fertile hybrids used in breeding programs (POMMER, 2009).

The occurrence of a larger secondary constriction observed in $V$. champinii and $V$. girdiana could be associated to a higher requirement of ribosomes for their growing and fructification in an adverse condition of less water resource in the drier environment they occur since they have shown higher drought tolerance when compared with the other species studied (REISCH; PRATT, 1996; PADGETT-JOHNSON et al., 2003).

It was seen one chromosome pair with a terminal NOR band after silver impregnation. This pair must be the same seen with secondary constriction and satellite segment at the end of long arm after Giemsa staining. However, there are reports about vinifera varieties showing not only one, but also two or up to three chromosome pairs with sc and sat with different sizes (TAKUSAGAWA, 1952; RAJ; SEETHAIAH, 1973; PATIL; PATIL, 1992, for instance). In populations of Vicia hybrida, for instance, the number of chromosome carrying sc and sat segment varied from 1 to 3 pairs (VENORA, et al. 2008).

These variations within the genus Vitis until now exclusive to $V$. vinifera species could be interpreted as a consequence of unequal translocations between one chromosome pair with sc and other pair without sc site. Moreover, it seems that the artificial and preferential crossings between cultivars for improving plant yield may allow or make easy asymmetric rearrangement events which can lead to enhancement of the NOR numbers. The karyomorphometric data and NOR banding recorded for the seven Vitis species analyzed, suggest that during the species diversification process the differences among them may have taken place at gene level, or at heterochromatin composition or still at chromosomal level expressed as variations associated with chromosome length probably reflecting losses of DNA segments in some of them or gains of repeated DNA segments in others. 
TABLE 1 - Mean values for total haploid chromosome length (THCL), the longest (L) and the shortest (S) chromosome length of the genome, for the longest to the shortest ratio (L/S), the longest and the shortest difference $(\mathrm{L}-\mathrm{S})$, the longest $(\mathrm{L} \%)$ e the shortest $(\mathrm{S} \%)$ chromosome length expressed as percentage and the average of centromeric index $(x \mathrm{CI})$ for Vitis species.

\begin{tabular}{llcccccccc}
\hline Var. & THCL $^{*}$ & $\mathbf{L}^{*}$ & $\mathbf{S}^{*}$ & $\mathbf{L} / \mathbf{S}$ & $\mathbf{L}-\mathbf{S}$ & $\chi \mathbf{c h r}$ & $\mathbf{\% L}$ & $\mathbf{\% S}$ & $\chi \mathbf{I C}$ \\
\hline V. champinii & $27.96^{\mathrm{a}}$ & $1.93^{\mathrm{a}}$ & $1.03^{\mathrm{a}}$ & $1.88^{\mathrm{a}}$ & $0.90^{\mathrm{a}}$ & $1.47^{\mathrm{a}}$ & $6.91^{\mathrm{b}}$ & $3.69^{\mathrm{a}}$ & $38.11^{\mathrm{a}}$ \\
V. cinerea & $23.24^{\mathrm{c}}$ & $1.70^{\mathrm{b}}$ & $0.89^{\mathrm{b}}$ & $1.93^{\mathrm{a}}$ & $0.81^{\mathrm{ab}}$ & $1.22^{\mathrm{b}}$ & $7.31^{\mathrm{ac}}$ & $3.80^{\mathrm{a}}$ & $38.12^{\mathrm{a}}$ \\
V. girdiana & $28.25^{\mathrm{a}}$ & $2.09^{\mathrm{c}}$ & $1.03^{\mathrm{a}}$ & $2.03^{\mathrm{a}}$ & $1.06^{\mathrm{a}}$ & $1.49^{\mathrm{a}}$ & $7.40^{\mathrm{a}}$ & $3.64^{\mathrm{a}}$ & $38.38^{\mathrm{a}}$ \\
V. labrusca & $20.55^{\mathrm{b}}$ & $1.57^{\mathrm{d}}$ & $0.78^{\mathrm{c}}$ & $2.02^{\mathrm{a}}$ & $0.79^{\mathrm{b}}$ & $1.08^{\mathrm{c}}$ & $7.63^{\mathrm{ac}}$ & $3.79^{\mathrm{a}}$ & $37.51^{\mathrm{a}}$ \\
V. rotundifolia & $21.92^{\mathrm{bc}}$ & $1.61^{\mathrm{b}}$ & $0.75^{\mathrm{c}}$ & $2.17^{\mathrm{a}}$ & $0.87^{\mathrm{a}}$ & $1.10^{\mathrm{c}}$ & $7.02^{\mathrm{b}}$ & $3.57^{\mathrm{a}}$ & $37.68^{\mathrm{a}}$ \\
V. rupestris & $21.68^{\mathrm{bc}}$ & $1.61^{\mathrm{b}}$ & $0.86^{\mathrm{b}}$ & $1.88^{\mathrm{a}}$ & $0.76^{\mathrm{b}}$ & $1.14^{\mathrm{bc}}$ & $7.19^{\mathrm{bc}}$ & $3.71^{\mathrm{a}}$ & $38.45^{\mathrm{a}}$ \\
V. vinifera & $22.83^{\mathrm{bc}}$ & $1.68^{\mathrm{b}}$ & $0.85^{\mathrm{b}}$ & $1.97^{\mathrm{a}}$ & $0.82^{\mathrm{ab}}$ & $1.19^{\mathrm{bc}}$ & $7.40^{\mathrm{ac}}$ & $3.75^{\mathrm{a}}$ & $38.14^{\mathrm{a}}$ \\
\hline
\end{tabular}

Means followed by the same letter $=$ differences were not significant at the level of $1 \%$ after $\mathrm{F}$ test.

Means followed by different letters $=$ differences were significant at the level of $1 \%$ after $F$ test.

*Mean values expressed in $\mu \mathrm{m}$.

TABLE 2 - Karyotype formulae (KF) and Asymmetry index values, TF\%, Stebbins (Stebb), A1 and A2 (Romero Zarco) components, and Paszko CVcl and CVci components with the respective AI for Vitis champinii, V. cinerea, V. girdiana, V. labrusca, V. rotundifolia, V. rupestris and V. vinifera.

\begin{tabular}{lcccccccc}
\hline Sp & KF & TF\% & Stebb & A1 & A2 & CVcL & CVci & AI \\
\hline I. champinii & $7 \mathrm{~m}+12 \mathrm{sm}$ & $37.68^{\mathrm{a}}$ & $2 \mathrm{a}$ & 0.38 & 0.12 & 12.24 & 5.67 & 0.69 \\
I. cinerea & $7 \mathrm{~m}+12 \mathrm{sm}$ & $37.69^{\mathrm{a}}$ & $2 \mathrm{a}$ & 0.38 & 0.04 & 4.10 & 5.01 & 0.21 \\
I. girdiana & $7 \mathrm{~m}+12 \mathrm{sm}$ & $36.63^{\mathrm{a}}$ & $2 \mathrm{~b}$ & 0.37 & 0.10 & 10.07 & 7.09 & 0.71 \\
I. labrusca & $7 \mathrm{~m}+12 \mathrm{sm}$ & $37.49^{\mathrm{a}}$ & $2 \mathrm{~b}$ & 0.38 & 0.08 & 8.36 & 4.75 & 0.40 \\
I. rotundifolia & $8 \mathrm{~m}+12 \mathrm{sm}$ & $35.48^{\mathrm{a}}$ & $2 \mathrm{~b}$ & 0.38 & 0.03 & 2.73 & 4.03 & 0.11 \\
I. rupestris & $8 \mathrm{~m}+11 \mathrm{sm}$ & $37.99^{\mathrm{a}}$ & $1 \mathrm{~b}$ & 0.37 & 0.04 & 4.38 & 3.95 & 0.17 \\
I. vinifera & $8 \mathrm{~m}+11 \mathrm{sm}$ & $37.55^{\mathrm{a}}$ & $1 \mathrm{~b}$ & 0.38 & 0.07 & 6.72 & 4.30 & 0.29 \\
\hline
\end{tabular}

Means followed by the same letter $=$ differences were not significant at the level of $1 \%$ after Tukey test . Means followed by different letters $=$ differences were significant at the level of $1 \%$ after Tukey test.

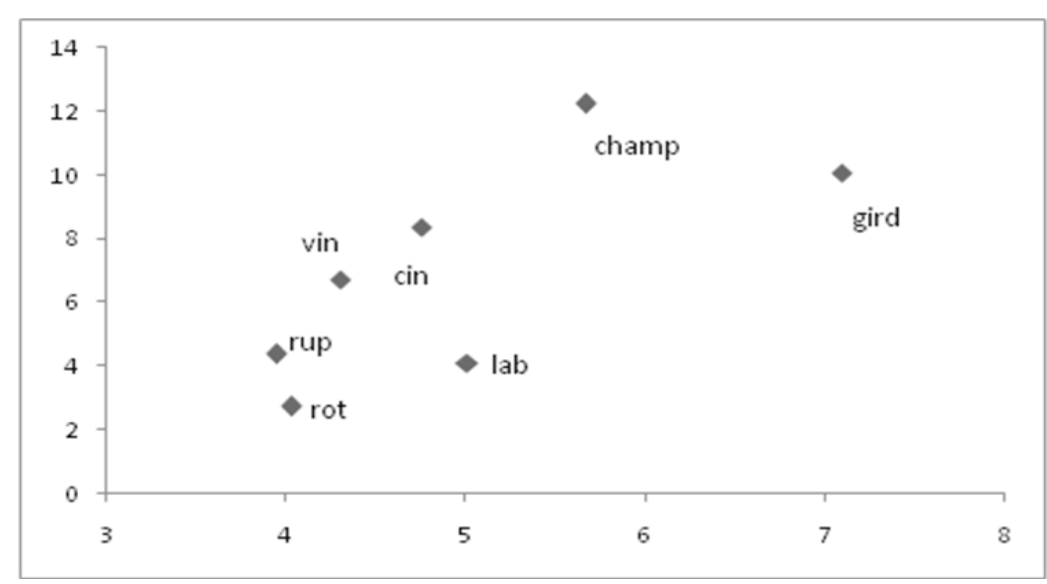

FIGURE 1 - Paszko's Scattered diagram for Vitis champinii (champ), V. cinerea (cin), V. girdiana (gir), $V$. labrusca (lab), V. rotundifolia (rot), V. rupestris (rup) and V. vinifera (vin). 


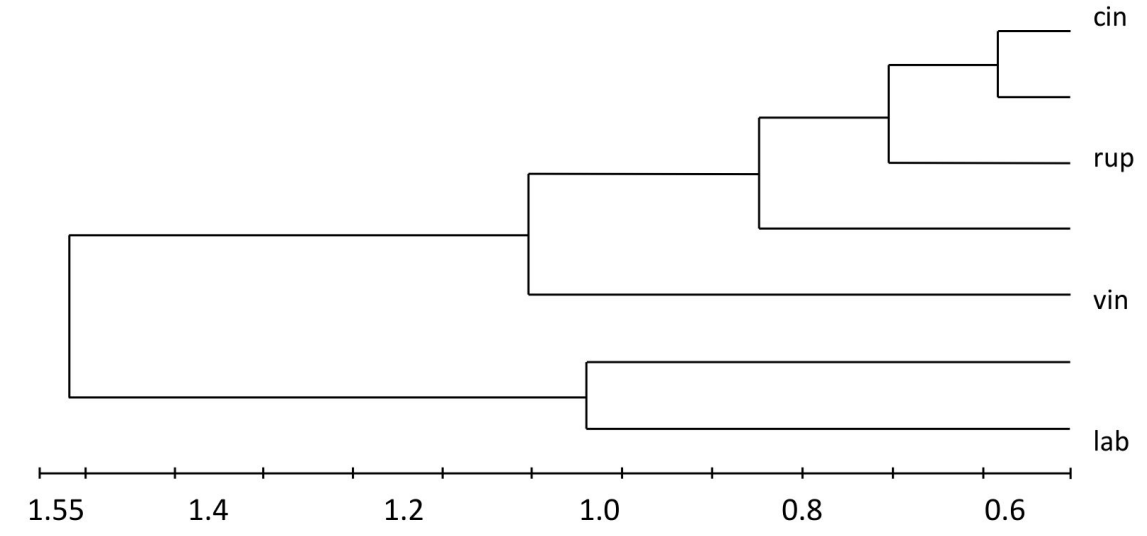

0.4

FIGURE 2 - Simplified dendrogram for Vitis based on Euclidian distances
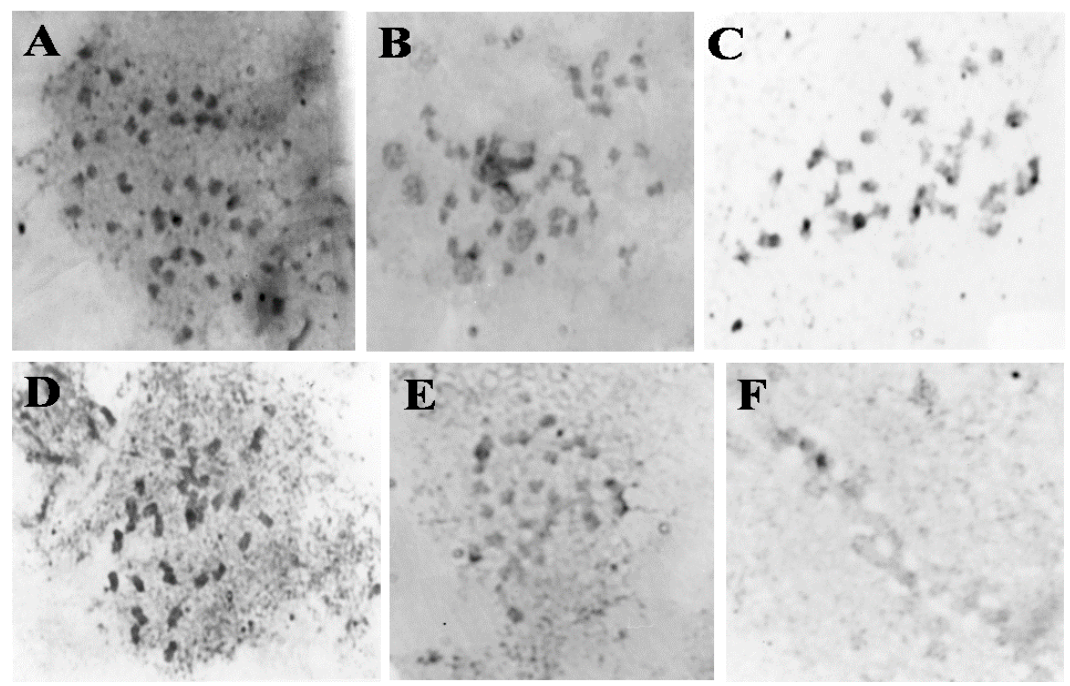

FIGURE 2 - Mitotic chromosomes of A- V. champinii; B- V. girdiana; C- V. labrusca;

D- $V$. rotundifolia; E- $V$. rupestris and F- $V$. vinifera after NOR-banding.

\section{CONCLUSION}

The chromosomal information obtained in the present research allowed species characterization and separation; and increased the knowledge for the genus and for the Vitaceae family since few species have been characterized by chromosome number and very few of them have a karyotype established. The data also may be used together with other grape approaches to the betterment of the comprehension of evolutionary tendencies into the genus.

\section{REFERENCES}

ALLEWELDT, G.; POSSINGHAM, J.V. Progress in grapevine breeding. Theoretical and Applied Genetics, Berlin, v.75, n.5, p.669-673, 1988.

ALVARENGA, A.A.; ABRAHÃO, E.; REGINA, M.A.; ANTUNES, L.E.C.; PEREIRA, A.F. Origem e classificação botânica da videira. Informe Agropecuário, Belo Horizonte, v.194, n.1, p.5-8, 1998. 
CAMARGO, U.A.; MAIA, J.D.G.; RITSCHEL, P.S.; REVERS, L.F. Grapevine breeding for tropical and subtropical environments in Brazil. In: WORLD CONGRESS OF VINE AND WINE, 30., 2007, Budapest. Proceedings... CD-ROM.

GOLDBLATT, P.; JOHNSON, D.E. Index to plant chromosome numbers 2001-2003: monographs in systematic. St. Louis: Missouri Botanical Garden, 2006. 106p .

HOWELL, W.M.; BLACK, D.A. Controlled silverstaining of nucleolus organized regions with a protective colloidal developer: a 1-step method. Experientia, Basel, v.36, n.9, p.1014-1015, 1980.

HUZIWARA, Y. Karyotype analysis in some genera of Compositae I. Karyotype of Japanese Eupatorium. Cytologia, Tokyo, v. 21, n.2, p.114-123. 1956.

LEVAN, A.; FREDGA, K.; SANDBERG, A.A. Nomenclature for centromeric position on chromosomes. Hereditas, Lund, v.52, n.2, p. 210-220, 1964.

MARTENS, M.H.R.; REISCH I. An improved technique for counting chromosomes in grapes. HortScience, Palo Alto, v. 23, n. 8, p. 896-899, 1988.

MITANI, N.; AZUMA, A.; FUKAI, E.; HIROCHIKA, H.; KOBAYASHI, S. A retrotransposoninsert $V v m y b A l a$ allele has been spread among cultivars of $V$. vinifera but not North American or East Asian Vitis species. Vitis, Berlin, v. 48, n.1, p.55-56, 2009.

MOORE, M. O. Classification and systematics of Eastern North American Vitis L. (Vitaceae) North of Mexico. Sida, Fort Worth, v.14, n.3, p. 339-367, 1991.

MYLES, S.; CHIA, J.-M.; HURWITZ, B.; SIMON, C.; ZHONG, G.Y.; BUCKLER, E.; WARE, D. Rapid genomic characterization of the genus Vitis. Public Library of Science, Bethesda, v. 5, n.1, p.1-9, 2010.

OLMO, H.P. 1937. Chromosome Numbers in the European Grape (Vitis vinifera). Cytologia, Tokyo, n.2, p. 606-613, 1937.

OLMO, H.P. Grapes. In: SIMMONDS, N.W. (Ed.). Evolution of crop plants. New York: Longman Group, 1979. p.294-298.
PADGETT-JOHNSON, M.; WILLIAMS, L.; WALKER, A. Vine water relations, gas exchange, and vegetative growth of seventeen Vitis species grown under irrigated and non irrigated conditions in California. Journal of American Society of Horticultural Science, Palo Alto, v.128, n.2, p. 269-276, 2003.

PALOMINO, G.; MARTÍNEZ, J.; MÉNDEZ, I. Karyotype studies in cultivars of Agave tequilana Weber. Caryologia, Firenze, v. 61, n.2, p.144-153, 2008 .

PASZKO, B. A critical review and a new proposal of karyotype asymmetry indices. Plant Systematics and Evolution, Vienna, v.258, n.1, p. 39-48, 2006.

PATIL, S.G.; PATIL, V.P. Karyomorphology of Vitis vinifera, $V$. rotundifolia and their hybrid. Cytologia, Tokyo, v. 57, n.1, p. 91-95, 1992.

POMMER, C.V. The impact of breeding on fruit production in warm climates of Brazil. Revista Brasileira de Fruticultura, Jaboticabal, v. 31, n.2, p. 612-634, 2009.

RAJ, A.S.; SEETHAIAH, L. Karyotype analysis and meiotic studies in three varieties of grape $(V$. vinifera L.). Cytologia, Tokyo, v. 34, n. 3, p.475-483. 1969. RAJ, A.S.; SEETHAIAH, L. Cytological studies in grape (Vitis vinifera L.). Cytologia, Tokyo, v. 38, n.4, 549-557, 1973.

REISCH, B.I.; PRATT, C. Grapes. In: JANICK, J.; MOORE, J.N.(Ed.). Fruit Breeding: vine and small fruits. New York: John Wiley \& Sons Incorporation, 1996. p. 297-369.

ROHANI, M.; MOHAMMADI, A.; KHOSROSHAHLI, M.; AHMADI, H.; DARANDEH, N. Karyotype analysis of several ecotypes of Capsicum annuиm L. in Iran. Notulae Botanicae Horticultural and Agrobotanica Cluj, Cluj Napoca, v.38, n.1, p.177-180, 2010.

ROMERO ZARCO, C. A new method for estimating karyotype asymmetry. Taxon, Vienna, v.35, n.3, p.526-530, 1986.

SOUSA, J.S.I. Uvas para o Brasil. Piracicaba: FEALQ, 1996. 791p. 
STEBBINS, G.L. Longevity, habitat, and release of genetic variability in the higher plants. Cold Spring Harbor Symposia on Quantitative Biology, New York, v.23, n.1, p.365-378, 1958.

TAKUSAGAWA, H. Chromosome numbers in Vitaceae. Japanese Journal of Genetic, Mishima, v.27, n.1, p. 22-24, 1952.

THIS, P.; LACOMBE, T.; THOMAS, M.R. Historical origins and genetic diversity of wine grapes. Trends in Genetics, Amsterdam, v.22, n.9, p.511519, 2006.1952.
VENORA, G.; RAVALLI, C.; CREMONINI, R. The karyotype as a tool to identify plant species: Vicia species belonging to Vicia subgenus. Caryologia, Firenze, v.61, n. 3, p. 300-319, 2008.

VILJOEN, T.A.; SPIES, J.J. Cytogenetical studies of three Vitis species. Vitis, Berlin, v.34, n.3, p.221224, 1995. 